\title{
Woolly Stories: An Art-Based Narrative Approach to Place Attachment
}

\author{
Kendra D. Stiwich, Lindsay J. McCunn, Chantey Dayal
}

\begin{abstract}
When people join an institution, no assurance of positive social connection exists. The mechanisms of psychological attachment to institutions are not well understood. However, place attachment is a predictor of individual well-being and, when correlated with life satisfaction and neighborhood ties, can enhance civic engagement and social trust. Research suggests that narratives can be a symbolic mechanism of place attachment. Thus, to increase place attachment in the parent population at a small elementary school, various art-based narrative activities were carried out as part of the OurSchoolOurStories project. Creating a storied blanket was one activity. Seven women needle-felted nine squares with the theme of representing some aspect of what the school meant to them. In a circle, they shared many stories including where they came from, how they came to be at the school, and their experiences at the school. Through these artistic narratives, participants were able to share much about their place identities, which allowed for social connection, and a sense of integration within the group.
\end{abstract}

KEYWords Place attachment, social bonding, place identity, narrative, textile art

I realize the power of art that does not hang on the walls of galleries.

\section{- Marina Abramovic}

The following is written primarily in K. Stiwich's voice. However, the research involved many perspectives, both from the research team and from the community. A sample of these voices is presented herein to shed light on how the community approached, responded to, and reflected on the research process. These voices are noted accordingly.

A year ago I did not understand Abramovic's quote. Or, perhaps it would be better to say that I did not know this quote. I had heard it but could not find within myself a true example of what it describes. This study is the story of how I came to know. The experience unfolded in a small group of mothers whose words and art inspired and made possible my research. I am grateful for their contributions to my research, but more significantly I am indebted to the sharing and community building inherent in their actions and being.

Place attachment is a complex and intriguing psychological construct that contains the emotional and cognitive bonds we form toward certain places (Scannell \& Gifford, 
2017). A growing body of interdisciplinary literature demonstrates the benefits of place attachment, including its prediction of individual well-being (Theodori, 2001), correlation with life satisfaction, neighborhood ties, and trust of people (Lewicka, 2011), enhancing civic engagement and social trust (Stefaniak, Bilewicz, \& Lewicka, 2017), and its association with human memories, belonging, positive emotions, and activity support (Scannell \& Gifford, 2017). It is this breadth of influence and outcome that piqued my interest in identifying potential mechanisms that lead to place attachment. After all, if community groups can better understand the activities or circumstances that preclude place attachment, it follows that they may encourage place attachment to develop and flourish.

\section{Place}

I conduct research at Sunrise Waldorf School in the Cowichan Valley on Vancouver Island, British Columbia. The school is located on a beautiful seven-acre rural property and enjoys mountain, forest, and farmland scenery. Sunrise is an independent school with students from pre-school to grade eight. I have been a member of the school for almost a decade and understand some of the ways in which place attachment may form toward the school setting, such as social, service, and requisite activities parents and guardians regularly partake in. I am sincerely interested in investigating the potential role that art and story play in the development and experience of place attachment. To test how these new aspects associated with place attachment toward the school, I decided to organize two groups (needle-felters and painters) to participate in creative activities that resulted in place-based artistic products. This paper describes the process and insights of creating a 'storied blanket' using the needlefelting technique. I also edited an unpublished book available to the Sunrise community to document artistic works (Stiwich, 2017a) whereby each participant was given the opportunity to include a narrative about their contribution. Portions of these stories are included below (with permission from participants).

\section{Purpose}

We coined the study the "OurSchoolOurStories (OSOS) Project." One of its main aims was to investigate the effects of exposure to place-based narratives on place identity and social bonding for the school's parent and guardian population. I adapted a model that incorporates personal, social, and environmental factors concerning how people attach to place (Raymond, Brown, \& Weber, 2010). An initial survey revealed that a portion of the sample was not attaching to the school through social and personal mechanisms as strongly as other segments of the population (Stiwich, 2017b). This observation led me to consider how people attach to an environment in the first place, particularly in personal and social ways. The following quotation offers C. Dayal's perspective on how she perceived the research as both an administrator and parent at Sunrise:

Kendra's impulse to create a community piece of art work through the reflection of our school was both inspiring and necessary. With our busy schedules, and sometimes

Engaged Scholar Journal: Community-Engaged Research, Teaching and Learning 
isolated Western culture, we forget the importance of gathering in a circle for the sake of sharing stories, time, and ourselves with one another. As the Director of Admissions at Sunrise Waldorf School, I have the pleasure of meeting and knowing all of our families through the intake process, but nothing compares to really getting to know one another. Speaking for myself, I can say that the opportunity to share our stories in a creative and meaningful way builds my compassion for others, my ability to listen, and meets my need to be known. (C. Dayal, personal communication, February 10, 2018)

\section{Methods}

The creation of the storied blanket involved seven women needle-felting nine squares with the theme of representing some aspect of what the school meant to them. The process began with a 12 inch square of white melton (a wool fabric) that served as a canvas. Then, multiple layers and strands of colored wool roving were felted onto the melton using special barbed needles. Scenes can quickly be created with robust color and texture (see Figure 1).

From personal experience, the art of needle-felting can be quite therapeutic and satisfying. It also allows for conversation-an integral part of our circles at the school.

\section{Reflections}

I found myself in the roles of both researcher and participant in this project. The study's intention was simple: bring people together to tell stories of the school while creating a place-based piece of art. We shared many tales that revolved around where we came from,

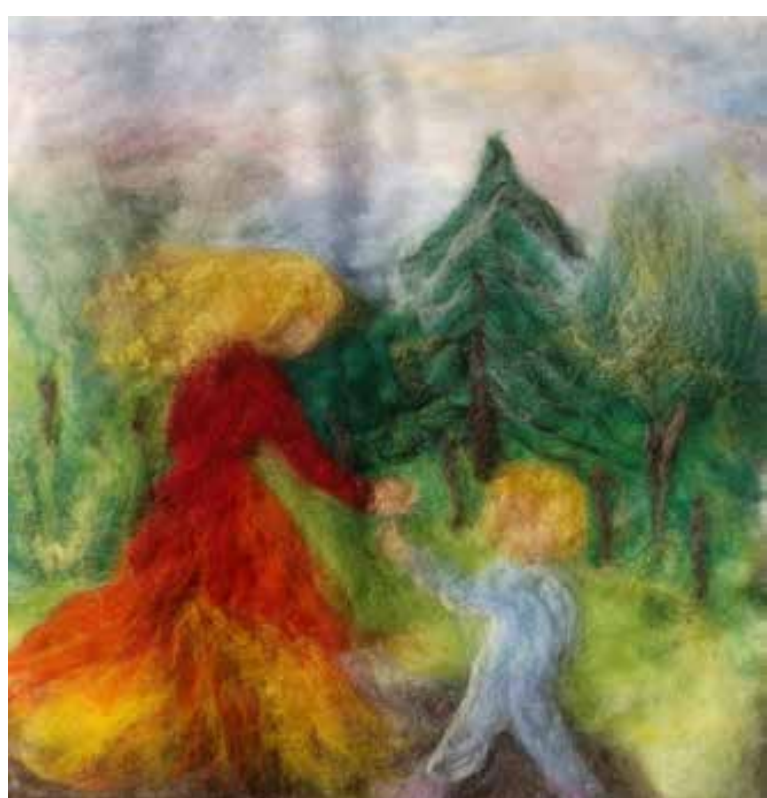

Figure 1. 'Gather', K. Lampson how we came to the school, and our experiences once there. There were moments of loss and pain, and others of laughter and mirth. We noted the beauty of the place, the peace we are able to find in this small nook of the world, and the nurturing environment we had found for our children. The following excerpt from a mother's story exemplifies some of these themes. It has a particular power in the school's community because of the imagery of the spiral which is a central theme during the winter festivals at the school.

This evokes memories of my daughter's first Advent spiral. She was in preschool; the classroom was dimly lit with candle light there was harp music playing in the 
background. It was so magical and peaceful. The children started to walk the cedar spiral that was dotted with all the elements of advent. Each carefully holding their red apple candle holder with a sense of awe and reverence, it felt as if time had stopped and this moment was going to last forever. Once all the children had carefully placed their lit candles on the cedar boughs the room was all a glow in warm soft light. We sat and held the feeling of peacefulness all looking toward the spiral filled with red apples, green boughs and a soft yellow glow. The warm tranquil calmness felt all-encompassing and it has left me with this magical memory for life. (S. Thomas describing 'Advent' in Stiwich, 2017a)

Through these artistic narratives, participants shared their individual place identities and, in many cases, their stories overlapped in context or theme which allowed for social connection and a sense of integration within the group. We came to know each other, and the place, in such a rich and integrated way. By way of creating the blanket, we were able to record and store our social and place-based knowledge in a storied artistic expression. The following narrative provided by another participant sums up the integrative nature of our art:

The two birds in this felting represent the individual and the partnership. The Yin and the Yang. The up and the down so to say. The journey of Waldorf Education for each of us as educators, parents, and student has many sides and a multitude of expressions. It is a journey that has helped me to accept the many layers and perspectives that exists in everything. (C. Dayal, describing 'Together' in Stiwich, 2017a)

Place attachment can be made possible "through psychologically and socio-culturally symbolic mechanisms such as art and language” (Scannell \& Gifford, 2017, p. 265). I hoped that by creating an artistic product, and sharing the stories embedded in the works, we would be able to tap into the social empathy within the community and increase attachment to the place itself. At the start of the project, my focus on creating a blanket was derived from needing an independent variable in my scholarly research to fulfill my degree. I needed the blanket to measure how others reacted to a stimulus. Now, in reflection, the impact of the physical creation process, and the interactions within the group, helped me most in realizing the potential power of this methodology. My own place identity and social bonding were strongly mediated by the artistic experience, and my observations of others suggest that I am not the only one. Others also observed these interactions as indicated in the following:

Each of the parents who were in the workshop with me, showed a side of themselves that I had not yet known. From that creative time together, we now pass each other in the halls, or in town, having had a deeper connection with one another. We have a little more patience, a little less shyness, and a piece of art in the world that reflects our diversity as well as our common ground. (C. Dayal, personal communication, February 10, 2018) 
Kellman (1998) describes the relationship between narratives, places, and individuals as "especially important for it serves as a grounding for a great deal of artmaking in many cultures and diverse circumstances" (p. 37). She uses a handful of examples to describe how aesthetic, narrative, and imaginative responses allow for people to remember and memorialize important places at an individual level. She concludes with an observation that "it is the particularity of each place and the remembered richness of each story that precipitates meaning for both individual and community." (Kellman, 1998, p. 40)

When I began the OSOS project, I wondered whether our woolly stories would precipitate our collective place-based experience and, ultimately, communicate those experiences to others. Today, on the other side of the creative process, I understand the naivety of my contemplation. It was entirely a matter of communication; a type of collective expression that simultaneously incorporated our storied words along with the weaving of texture, color, emotion, history, and self. One panel is, in and of itself, a rich record of place experience and attachment. Taken together, the piece is a powerful, aesthetic, tactile representation of our communal attachment. Another narrative shared in the book explores one aspect of place experience:

One of my favorite festivals is the lantern walk -- how we come together to shine our lights in the darkness. Sunrise is for me like a bright light in the community, and in the world where the forces of darkness can seem close at hand. I love all the symbolism of these fragile yet beautiful lights in a dark night, in a dark time of year. (M. Smith describing 'Light in the Darkness' in Stiwich, 2017a)

The study's small sample of women were certainly not the first to experience the communal benefits of group textile art. For millennia, people have been working with a variety of fibrous materials from local plants and animals. Research into the reasons people, and in particular women, are drawn to the fiber arts in group contexts exists. One investigation notes how handcrafting afforded women a sense of place and connected them to their local histories (Johnson \& Wilson, 2005). Another examination describes other benefits of the craft, such as an enhanced sense of self, greater collective identity, and a deeply spiritual experience (Riley, 2008). Garlock (2016) notes that "fabric has been used, and continues to be used, for expression of identity, social status, secrets, and stories" (p. 59). By creating these story cloths, memory cloths, narrative textiles, story blankets, and arpilleras, individuals are able to express a deep personal knowledge of themselves and their worlds. This is a powerful act of agency and seems to be utilized globally. Within the pieces, symbols of origin, village, family, and ultimately self, emerge. During our felting, a particularly poignant piece was shared from one mother who was transitioning to the school after having recently moved to the area. This is a sentiment many of the school's parents and guardians respond to because a large proportion are not originally from the area:

When I started this piece I was in a place of nostalgia and sadness, thinking about the home that our family left behind to be here on Vancouver Island and at Sunrise 
Waldorf School. I grew up in a little town in Ontario that was well known for its beautiful sunsets over Lake Huron. I find it interesting that my first instinct when asked to create an art piece was to create a picture reminiscent of my home town, this indeed was a true reflection of the "holding on" feeling I was experiencing at the time. When I returned to the piece a couple weeks later to complete it, I was feeling more hopeful and connected to this new corner of the Earth I occupy. It no longer was just a picture of a Sunset from my little hometown in Ontario but now a bridge between an old life and the potential that lay before me, a new life. I finished the piece depicting a Sunset over the Ocean instead of my home town Lake. This was my way of expressing my love of where I come from and the hope, excitement and trepidation I sometimes feel stepping into this new life, in a new place with new people. Sunrise it is. (M. White describing 'Sunrise' in Stiwich, 2017a)

There is more to these textile groups and circles than just the physical materialization of the created works. There is also the art of storytelling that layers over, and weaves within, the people and the place. Low's 1992 typology of cultural place attachment outlines six kinds of symbolic links between people and land including narratives via storytelling and place naming. She states that "narrative creates place attachment through talking about place, either through storytelling or naming; the linguistic act of narrating is the process by which attachment occurs" (p. 167) and that "people's linkage to the land is through the vehicle of the story and identified through place naming and language" (pp. 173-4). This resonates with Tuan's (1975) statement that "to know a place is also to know the past" (p. 164), as well as Backlund and Williams's (2003) ideas that attachment to place can occur with no experience with the place simply through hearing stories and memories from others. One of my own contributions affords an example of a memory I shared of Sunrise. During the sharing, many people were engaged evidenced through head nods, laughter and further commentary.

I remember one of my first Winter Fairs and we had a DUMP of snow - heaps of it everywhere and all these people had to come and shovel the roof, the walkways, the driveway - it was crazy. We were running the barbeque as a class event and watching [my husband] negotiate the Honda Fit and a barbeque through all that still makes me smile. It was one of the best fairs. Not just because we actually pulled it off, but also that we had to give over to the mirth and hilarity of the situation. I laughed so much and so hard. What a winter celebration! I learned that I could count on people to haul my barbeque out and over a snow drift while they are cold, soaking wet, and mildly exhausted. All the while sporting a face splitting grin. It is a fair we still talk about. (K. Stiwich describing 'Friends' in Stiwich, 2017a)

Arguably, story-telling is one way for humans to share our internal experiences and offer descriptions of ourselves to others. People can appreciate the intimacy of hearing another's story, especially when it is presented as raw narrative art, steeped in folk vernacular. During my experience with the OSOS project, most of the participants shared many stories of the school.

Engaged Scholar Journal: Community-Engaged Research, Teaching and Learning 
We could not help but retell the first time we came to the school and how we were struck by its beauty and magic. We shared thoughts of social uncertainty within the confines of a new group. In the end, if I were to choose a most affecting memory, it would be watching two particular mothers. One of whom had never needle-felted in her life was new to Waldorf education, and the community as a whole (see Figure 2). In the circle, she sat next to a woman who was raised in an anthroposophical community who had taught needle-felting to others many times before. Anthroposophy is the guiding philosophy behind the Waldorf school movement, it has also influenced other social, economic, and creative sectors such as agriculture, architecture and community development. Throughout my research with Sunrise a popular quote by the founder of anthroposophy Rudolf Steiner has guided me: "A healthy social life is found when in the mirror of each

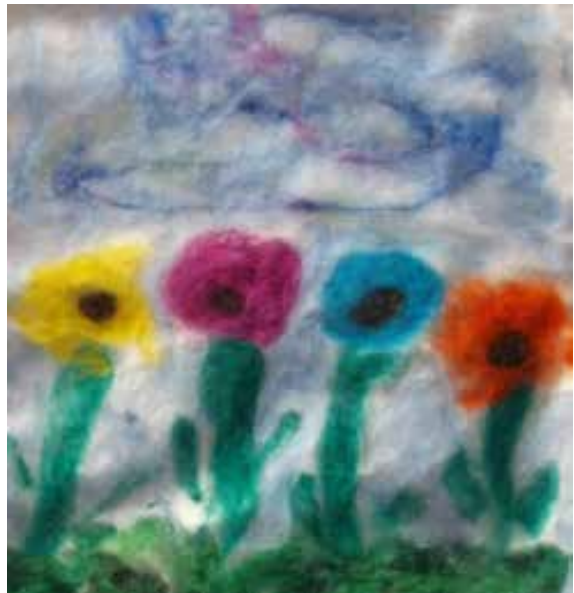

Figure 2. T. Vogelaar human soul, the whole community is shaped, and when in the community, lives the strength of each human soul" (1927/1993). Listening to the two participants share and mirror their experiences, and mutual appreciation, was one of the simple, yet complex, social bonding mechanisms that the project was intended to facilitate, capture, and hold dear.

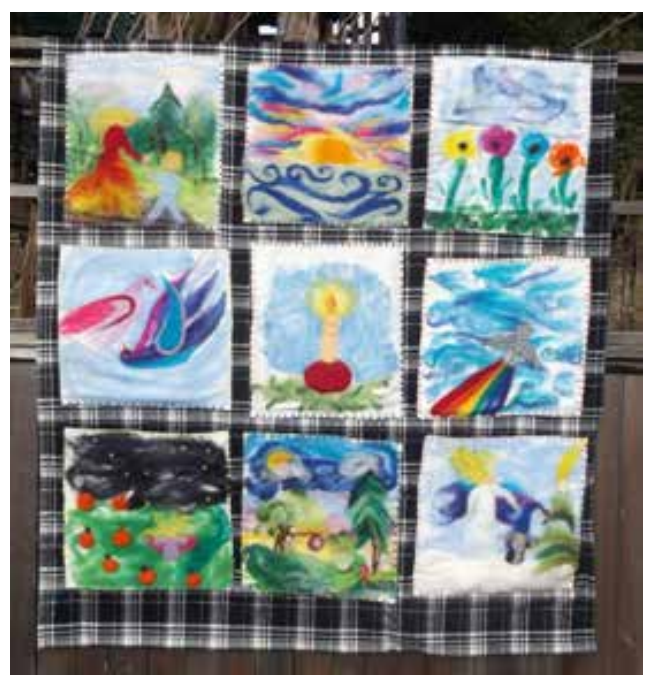

Figure 3. Needle-felted community blanket

\section{Concluding Remarks}

When I look at the final piece, it warms my heart to see that my part is just one part. That together we can make something much more beautiful. It is a demonstration of the many layers and aspects of Waldorf Education and is also reflective of the voice of the parent, without whom the school, would and could not exist. (C. Dayal, personal communication, February 10, 2018)

The words above beautifully summarize the intent and potential result of my research both in its power for community bonding and selfidentity within the community. When we each walked away from the circle, we returned to our own lives. Undoubtedly, what we left behind, and what we take forward from the experience, speaks to identity and social bonding with the school. I have materialized a part of who I am 
in that place for others to experience. I have given a part of myself, a texturizing for public display. If nothing else, I have made my place attachment a social reality while witnessing others go through this same process. Our blanket (see Figure 3) may not hang in a gallery, but its power has become lovingly apparent for this humbled researcher.

\section{Acknowledgements}

Funding for this study was provided by the Sunrise Waldorf Parents' Association.

\section{About the Authors}

Chantey Dayal is a painter, mother, teacher, and currently the Director of Admissions at Sunrise Waldorf School in Duncan, British Columbia. Being a part of a Waldorf School Community for over a decade has shaped, and continues to inspire, her family life and personal education.

Lindsay J. McCunn, PhD is a professor and environmental psychologist at Vancouver Island University. She supervises undergraduate and graduate students in their examinations of human transactions with built and natural settings. Lindsay's research centers on place attachment, place identity, and place dependence in a number of environments.

Kendra Stiwich (corresponding author) is the Student Research Engagement Coordinator at Vancouver Island University (VIU). She holds degrees in psychology and anthropology with an overarching theme in her research being people's engagement with the world around them. Kendra examines topics from pre-historic hunter-gatherer mobility to identity to the importance of undergraduate research. Email: kendra.stiwich@viu.ca 


\section{References}

Backlund, E. A., \& Williams, D. R. (2003, April). A quantitative synthesis of place attachment research: Investigating past experience and place attachment. In J. Murdy (Ed.), Proceedings of the 2003 Northeastern Recreation Research Symposium (pp. 320-325). Newton Square, PA: USDA Forest Service.

Brown, G., Raymond, C. M., \& Corcoran, J. (2015). Mapping and measuring place attachment. Applied Geography, 57, 42-53.

Garlock, L. R. (2016). Stories in the cloth: Art therapy and narrative textiles. Art Therapy, 33(2), 58-66.

Johnson, J. S., \& Wilson, L. E. (2005). 'It says you really care': Motivational factors of contemporary female handcrafters. Clothing and Textiles Research Journal, 23(2), 115-130.

Kellman, J. (1998). Telling space and making stories: Art, narrative, and place. Art Education, 51(6), $35-40$.

Lewicka, M. (2011). Place attachment: How far have we come in the last 40 years?. Journal of Environmental Psychology, 31(3), 207-230.

Low, S. M. (1992). Symbolic ties that bind. In S. M. Low \& I. Altman (Eds.), Place Attachment (pp. 165-185). New York: Springer.

Raymond, C. M., Brown, G., \& Weber, D. (2010). The measurement of place attachment: Personal, community, and environmental connections. Journal of Environmental Psychology, 30(4), 422434.

Riley, J. (2008). Weaving an enhanced sense of self and a collective sense of self through creative textile-making. Journal of Occupational Science, 15(2), 63-73.

Scannell, L., \& Gifford, R. (2017). The experienced psychological benefits of place attachment. Journal of Environmental Psychology, 51, 256-269.

Stefaniak, A., Bilewicz, M., \& Lewicka, M. (2017). The merits of teaching local history: Increased place attachment enhances civic engagement and social trust. Journal of Environmental Psychology, 51, 217-225.

Steiner, R. (1993). Understanding the Human Being: Selected writings of Rudolf Steiner. R. Seddon (Ed.). Bristol, U.K.: Rudolf Steiner. (Original work published in 1927)

Stiwich, K. D. (Ed.). (2017a). OurSchoolOurStories 2017: Stories, Art and Photography by Parents and Guardians of Sunrise Waldorf School. Unpublished manuscript.

Stiwich, K. D. (2017b). Report of the 2017 Parent and Guardian Survey. Unpublished manuscript.

Theodori, G. L. (2001). Examining the effects of community satisfaction and attachment on individual well-being. Rural Sociology, 66(4), 618-628.

Tuan, Y. F. (1975). Place: an experiential perspective. Geographical Review, 151-165. 